\title{
CONCENTRATION AND COMPOSITION OF NATURAL URINE OF SOME MICHIGAN SMALL MAMMALS
}

\author{
Eugene H. Studier and Darlene A. Rimle \\ Department of Biology, The University of Michigan-Flint, Flint, Michigan 48503, U.S.A.
}

(Received 11 December 1979)

\begin{abstract}
Analysis of bladder urine of small mammals collected during the summer in Michigan shows that:

1. Snap-trapping rodents and insectivores can be an effective technique for collecting natural urine.

2. Individuals not immediately killed by the trap produce abnormally concentrated urine.

3. Natural urine is very dilute compared to maximum concentrating abilities of the species tested.

4. Brief periods of captivity $(<2 \mathrm{hr})$ do not significantly affect urine concentration in Eptesicus fuscus.
\end{abstract}

\section{INTRODUCTION}

Renal function aspects of water balance, particularly in reference to maximum urine concentrating capacity, have been increasingly investigated in recent years. Studies have utilized one or more of three basic experimental protocols. Urine for analysis has been collected from various species maintained in the laboratory for long periods of time under ad libitum and various restricted water regimes (see, for example, McFarland \& Wimsatt, 1969; Geluso, 1975, 1978; Deavers \& Hudson, 1979). In other studies, urine has been obtained from live-trapped, field-caged animals held briefly in captivity (Bradford, 1974; Mullen, 1970, 1971; Baudinette, 1974). Finally, urine has been collected from the bladder of animals that were shot (Bakko, 1975, 1977a) or from roosting bats (Geluso \& Studier, 1979).

Urine collected by the first two methods does not yield water halance estimates or urine component or total concentration levels indicative of natural conditions. Bakko (1977b) demonstrated that the livetrapped, field-cage technique cannot be used to obtain natural urine from the red squirrel, Tamiasciurus hudsonicus. Physiological responses due to trapping, handling and/or confinement result in urine component levels and total concentrations which differ significantly from those values in bladder urine taken from individuals shot and killed at the same time. Similar differences may also occur in comparing urine from long-term lab-caged individuals relative to feral individuals. The disparity is at least partially explained by hormonal changes associated with acute or prolonged stress from capture, handling and various durations of confinement.

It would seem that the only reliable methods for insuring collection of natural urine are procedures which result in the collection of urine present in the bladder just prior to the capture of the individual. Present reported methods which fit this criterion are collection of bladder urine from rodents which dic immediately upon being shot and collection of urine from roosting bats which regularly urinate immediately upon capture. Urine present in the bladder of snap-trapped mammals which die immediately must also have been present just prior to capture. The primary focus of this paper tests the advisability of snap-trapping as a technique for procuring natural urine samples and compares such natural urine with available data for laboratory caged individuals.

\section{MATERIALS AND MFTHODS}

Small mammals were snap-trapped in various habitats in Genesee County, Michigan, from late June through August 1979. Traps were set about $1 \mathrm{hr}$ before sunset, checked periodically throughout the night and retrieved about $1 \mathrm{hr}$ after sunrise. Notation was made whether each individual died immediately (central nervous system crushed or severed) or not (caught by leg or tail). Mice which were alive when found were killed by cervical dislocation. Sex, reproductive condition, age, and approximate time of capture was recorded for each animal. Dead animals were returned immediately to the laboratory where the abdominal cavity was opened to expose the bladder. When present, urine was collected by being allowed to flow down the wall of a microtube after puncturing the bladder with a scalpel blade.

Big brown hats were hand collected at sunrise $(7: 00 \mathrm{am}$ ) on 3 August 1979 in the attic of a building in Grand Blanc, Michigan. To facilitate rapid initial sample collection, each bat was caged individually in a 1-pint wide-mouth plastic container sealed with a ventilated plastic lid. All bats urinated within $10 \mathrm{~min}$ although most voided within $30 \mathrm{sec}$. Urine was collected with a plastic pipette and transferred to microtubes. Sex, reproductive condition, age and time of urine collection was recorded for each individual Caged bats were returned to the laboratory and covered with a cloth bag. A second urine sample was collected from each bat $2 \mathrm{hr}$ after the initial sample. To elicit urination, each bat was simply picked up. Additional samples were periodically collected from some individuals until sunset (8:00 p.m.) when bats were released.

Urine analyses for all samples were conducted similarly, As soon as possible after collection, osmotic pressure of undiluted urine was determined using a Wescor Model $5100 \mathrm{~B}$ micro-osmometer using $5 \mu \mathrm{l}$ aliquots of the original sample. All values are expressed in osmolality, i.e. $\mathrm{mOsm} / \mathrm{kg}$ water. Standards of 290 and $1000 \mathrm{mOsm} / \mathrm{kg}$ were used. After appropriate dilution $(1: 100)$, urine sodium and potassium concentrations were measured by direct flame photometry with a Perkin-Elmer (Coleman 51) flame photometer. Levels of sodium and potassium are reported in mequiv/l. After a ten-fold dilution, urine ammonia and urea nitrogen levels were determined by a micro-modification of a colorimetric procedure (Connerty et al, 1955) using a Beckman 151 spectro-colorimeter. Values are expressed as $\mathrm{mg} \%$. 
Table 1. Numbers of each species collected, numbers of individuals from which samples were obtained (equals sample size), and total $(\mathrm{OP}=$ osmotic pressure) and component concentration in urine samples

\begin{tabular}{|c|c|c|c|c|c|c|}
\hline Spccics & $\begin{array}{c}\text { No. trapped } \\
(: /\langle\hat{j})\end{array}$ & $\begin{array}{c}\text { No. sampled } \\
(: / j)\end{array}$ & $\begin{array}{c}\mathrm{OP} \text { in } \\
\mathrm{mOsm} / \mathrm{kg}\end{array}$ & $\begin{array}{l}\mathrm{Na}^{+} \text {in } \\
\text { mequiv/l. }\end{array}$ & $\begin{array}{l}\mathrm{K}^{+} \text {in } \\
\text { mequiv/l. }\end{array}$ & $\begin{array}{c}\text { Urea in } \\
\mathrm{mg}^{\circ} \text {. }\end{array}$ \\
\hline \multicolumn{7}{|l|}{ P. leucopus } \\
\hline Total & $\begin{array}{c}51 \\
(24 / 27)\end{array}$ & $\begin{array}{c}15 \\
(3 / 12)\end{array}$ & $\begin{array}{l}925.0 \\
(134)\end{array}$ & $\begin{array}{l}98.6 \\
(3.7)\end{array}$ & $\begin{array}{l}76.2 \\
(3.3)\end{array}$ & $\begin{array}{l}309.6 \\
(33.7)\end{array}$ \\
\hline Killed immediately & & $\begin{array}{c}12 \\
(3 / 9)\end{array}$ & $\begin{array}{r}717.0 \\
(92)\end{array}$ & $\begin{array}{r}101.3 \\
(4.2)\end{array}$ & $\begin{array}{l}78.1 \\
(3.6)\end{array}$ & $\begin{array}{l}307.1 \\
(36.8)\end{array}$ \\
\hline Not killed immediately & & $\begin{array}{c}3 \\
(0 / 3)\end{array}$ & $\begin{array}{r}1757.0 \\
(114)\end{array}$ & $\begin{array}{l}87.6 \\
(3.0)\end{array}$ & $\begin{array}{l}68.7 \\
(8.7)\end{array}$ & $\begin{array}{l}319.6 \\
(99.7)\end{array}$ \\
\hline M. pennsylicanicus & $\begin{array}{c}8 \\
(7 / 1)\end{array}$ & $\begin{array}{c}2 \\
(1 / 1)\end{array}$ & 727.0 & 106.4 & 59.6 & 429.5 \\
\hline B. hrevicauda & $\begin{array}{c}6 \\
(3 / 3)\end{array}$ & $\begin{array}{c}6 \\
(3 / 3)\end{array}$ & $\begin{array}{l}761.0 \\
(140)\end{array}$ & $\begin{array}{l}144.0 \\
(11.5)\end{array}$ & $\begin{array}{l}71.2 \\
(3.6)\end{array}$ & $\begin{array}{l}267.4 \\
(64.5)\end{array}$ \\
\hline \multicolumn{7}{|l|}{ E. fuscus } \\
\hline First sample & $\begin{array}{c}15 \\
(13 / 2)\end{array}$ & $\begin{array}{c}15 \\
(13 / 2)\end{array}$ & $\begin{array}{r}1205.0 \\
(109)\end{array}$ & $\begin{array}{r}103.6^{*} \\
(9.9)\end{array}$ & $\begin{array}{l}61.7^{*} \\
(10.1)\end{array}$ & $\begin{array}{l}355.7^{*} \\
(34.9)\end{array}$ \\
\hline Second sample & $\begin{array}{c}15 \\
(13 / 2)\end{array}$ & $\begin{array}{c}15 \\
(13 / 2)\end{array}$ & $\begin{array}{r}1258.0 \\
(126)\end{array}$ & $\begin{array}{c}96.1^{*} \\
(2.8)\end{array}$ & $\begin{array}{r}63.0^{*} \\
(9.6)\end{array}$ & $\begin{array}{l}330.5^{*} \\
(38.1)\end{array}$ \\
\hline
\end{tabular}

* Sample size $=14$.

Values in parantheses below $O P$ and component concentration are standard errors.

\section{RFSLILTS}

Of the total snap-trapped mammals, $35.3 \%$ (23 of 65) contained sufficient bladder urine for analysis. Samples ranged from $<10 \mu \mathrm{l}$ to $>500 \mu \mathrm{l}$. All $B$. brevicauda provided sufficiently large samples for analysis. Of eight $M$. pennsyluanicus, two $(25 \%)$ retained sufficient bladder urine for analysis. Of 51 snap-trapped $P$. leucopus, $15(29.4 \%)$ contained enough bladder urine for analysis. Of 27 male $P$. leucopus, $12(44.4 \%)$ provided adequate samples while only three of 27 females $(11.1 \%)$ contained sufficient bladder urine for analysis. These results are summarized in Table 1 as are the results of urine analysis. Of the $15 P$. leucopus from which samples were obtained, three individuals were not immediately killed by the traps. I Jrine from these three mice was significantly more concentrated $(t=7.099 ; \mathrm{df}=13 ; P<0.001)$ than urine from the 12 mice which died immediately. Sodium levels in $P$. leucopus which were killed immediately by the traps were significantly higher $(t=2.654 ; \quad \mathrm{df}=13$; $P<0.02$ ) than those of mice not immediately killed by traps. All other snap-trapped mammals were immediately killed by the traps.

Table 1 also shows analysis results of urine collected from $E$. fuscus during the first two collection periods. Paired t-tests on the first and second samples show no significant changes in the measured urine variables comparing samples taken immediately upon capture (first sample) with those taken after $2 \mathrm{hr}$ in captivity (second sample) of the same individuals. Polynomial regression analysis of all samples taken from $E$. fuscus from 7:00 a.m. to 8:00 p.m. show no significant relationships between urine osmotic pressure or urine $\mathrm{Na}^{+}$concentration and time after capture. A significant curvilinear relationship does exist between urine $\mathrm{K}^{+}$level and time $(F=21.07$; 2 and $31 d f ; P<0.0001 ; r^{2}=0.576$ ) expressed by the following equation:

$\left[\mathrm{K}^{+}\right]$in mequiv $/ 1 .=$

$$
\begin{aligned}
& -1.102(\text { time })^{2}+18.26 \text { (time) }+26.12 \\
& \begin{array}{lll}
( \pm 0.237) \quad( \pm 3.21) & ( \pm 6.86)
\end{array}
\end{aligned}
$$

where time is hours after capture (7:00 a.m.) and values in parentheses are standard errors. A linear relationship exists between urea level and time $(F-5.07) ; 1$ and $\left.32 \mathrm{df} ; P=0.0314 ; r^{2}-0.137\right)$ as follows:

$$
\begin{aligned}
{[\mathrm{UREA}] \text { in } \mathrm{mg} \%=} & -10.37(\text { time })+370.4 \\
( \pm 4.61) & ( \pm 29.3) .
\end{aligned}
$$

\section{DISCUSSION}

Snap-trapping appears to be a reasonably effective method of obtaining natural urine spccimens from small mammals. Success of this procedure varied extensively among the three species collected by snaptrapping. The $100 \%$ success for B. brevicauda may relate to their natural diet and the observations of Deavers \& Hudson (1979) that these shrews consume larger quantities of low caloric, high water content food than many other small mammals. In view of their large intake of preformed water, Greater rates of urine formation and a greater probability of bladder urine being present seems more likely for shrews than for the rodents collected. Among the $P$, leucopus, the probability of oblaining urine samples from trapped males was almost significantly higher than for trapped females $\left(X^{2}=3.51 ; 1 \mathrm{df} ; 0.10>0.05\right)$. No urine samples were collectable from any female in middle through late pregnancy.

Differences in urine total osmotic pressure comparing $P$. leucopus not immediately killed by trapping with those which are consistent with Bakko's (1977b) observation that live-trapping, handling, and/or caging initiates physiological responses resulting in the production of highly concentrated urine. Natural urine can, therefore, be collected by snaptrapping only from individuals immediately killed by the traps.

Bladder urine collected in this study is well below the maximum urine concentrations found for these species. $P$. leucopus and $B$. brevicauda produced natural urine at $24.3 \%$ and $42.2 \%$, respectively, of their 
maximum renal concentrating abilities (Deavers \& Hudson, 1979). Although maximum urine concentration values for $M$. pennsylvanicus are not available, individuals sampled here produced urine at $41.4 \%$ of the maximum urine osmotic pressures reported for Clethrionomys gapperi, a related microtine (Deavers \& Hudson, 1979). Big brown bats contained urine which was at most $40.2 \%$ of the maximum urine osmotic pressures reported for this species (Geluso, 1978). The natural urine of the species studied was actually more dilute than urine concentrations of captive individuals reported by the previous authors under ad libitum water regimes. These mammals are, therefore, under no water stress during the summer in Michigan. These data support the concept that these species do not ingest given amounts of food or water for the purpose of maintaining water balance, i.e. by ingesting appropriate types and amounts of food items to maintain some other physiological balance, e.g. caloric, nitrogen, mineral, more than sufficient intake for water economy occurs. A similar situation appears to exist in Tamiasciurus hudsonicus in July in Minnesota which produce natural urine which is only $17.3 \%$ of maximum renal concentrating capacity (Bakko, 1977b). Natural urine collected from Myotis lucifugus in August in New Mexico, however, reached $90.9 \%$ of the maximum urine osmotic pressure determined for this species (Geluso \& Studier, 1979; Geluso, 1975). Little brown bats, therefore, utilize near maximum renal concentrating capacity at the time and place of sampling and total water intake barely meets water losses. Studies of squirrels (Bakko, 1975) and prairie dogs (Bakko, 1977a) indicate that marked seasonal variability exists in the extent of utilization of renal concentrating capacities as well as concomitant variability in water stress. As stated earlier, several small mammals produce natural urine which is significantly more dilute than urine produced by these same species under ad libitum water regimes in the laboratory. This observation argues for the possibility that mild stress of prolonged captivity affects renal function just as brief periods of caging do, although less profoundly. The possible effect of a brief period of captivity ( $2 \mathrm{hr}$ ) on renal function of $E$. fuscus was tested and no differences in total or component concentrations were found. Regression analysis of urine samples collected from these captive bats throughout their total normal roosting period showed no significant relationship of urine osmotic pressure with time. This lack of relationship is similar to that found for this species by Geluso (1975) under water stress conditions. Urine $\mathrm{K}^{+}$levels showed a significant rise throughout the 11-hr period of observation reaching a peat at $8.3 \mathrm{hr}$ after the initial collection. This rise would seem most likely due to a relatively parallel rise in circulating aldosterone levels. There existed, however, no change in urine $\mathrm{Na}^{+}$levels throughout the period of observation. Urine urea concentrations dropped linearly and significantly throughout the period of observation. This post-prandial progressive decline in urinary urea concentration is expected to result from the cessation of dietary protein digestion and assimilation. This phenomenon is documented (Levinsky \& Berliner, 1959; Schmidt-Nielsen \&
Robinson, 1970) by a mechanism described by Schmidt-Nielson (1977).

Both total and component concentrations for all species showed considerable variability. Many factors, such as sex, age, time of day, reproductive condition, etc., may contribute to the observed variability but cannot be adequately tested with the present sample.

Acknowledgements - We thank David Freed, David Rimle, Ada Feldman, Ernest Szuch and Beth Ann Szuch for aid in the ficld aspects of this study. Frank Mitoma of St Joseph Hospital, Flint, allowed us to use their osmometer. Drs Richard W. Dapson and Eugene B. Bakko provided many useful comments on the manuscript.

\section{REFERENCES}

BAKKO F. B. (1975) A field water balance study of gray squirrels (Sciurus carolinensis) and red squirrels (Tamiasciurus hudsonicus). Comp. Biochem. Physiol. 51A, $759-768$.

BAKKO E. B. (1977a) Field water balance performance in prairie dogs (Cynomys leucurus and $C$. ludovicianus). Comp. Biochem. Physiol. 56A, 443-451.

BAKKO E. B. (1977b) Influence of collecting techniques on estimate of nature renal function in red squirrels. $\mathrm{Am}$. Midl. Nat. 97, 502-504.

BaudinetTe R. V. (1974) The physiology of chronic water deprivation in the California ground squirrel (Spermophilus beecheyi): relevance to natural populations. $J$. Zool. Lond. 173, 159-171.

BradFord D. F. (1974) Water stress of free-living Peromyscus truei. Ecology 55, 1407-1414.

Connerty H. V., Briggs A. R. \& Eaton E. H., JR. (1955) Determination of blood urea nitrogen using a simple stabilizing reagent. Am. J. clin. Path. 25, 1321-1325.

Deavers I. R. \& Hudson J. W. (1979) Water metabolism and estimated ficld water budgets in two rodents (Clethrionomys gapperi and Peromyscus leucopus) and an insectivore (Blarina brevicauda) inhabiting the same mesic environment. Physiol. Zool. 52, 137-152.

Geluso K. N. (1975) Urine concentration cycles of insectivorous bats in the laboratory, J. comp. Physiol. 99. $309-319$

GeLuso K. N. (1978) Urine concentrating ability and renal structure of insectivorous bats. J. Mammal. 59, 312-323.

Geluso K. N. \& Studier E. H. (1979) Diurnal fluctuation in urine concentration in the little brown bat. Myotis lucifugus, in a natural roost. Comp. Biochem. Phisiol. 62A, 471-473.

LEVINSKY N. G. \& Berliner R. W. (1959) The role of urea in the urine concentrating mechanism. $J$. clin. Invest. 38, $741-748$.

McFarland W. N. \& Wimsatt W. A. (1969) Renal function and its relation to the ecology of the vampire bat, Desmodus rotundus. Comp. Biochem. Physiol. 28. 985-1006.

MULLEN R. K. (1970) Respiratory metabolism and body water turnover rates of Perognathus formosus in its natural environment. Comp. Biochem. Physiol. 32. 259265

MuLLEN R. K. (1971) Energy metabolism and body water turnover rates of two species of free-living kangaroo-rats, Dipodomys merriami and Dipodomys microps. Comp. Biochem. Physiol. 39A, 379-390.

SCHMIDT-NIELSEN B. (1977) Excretion in mammals: role of the renal pelvis in the modification of the urinary concentration and composition. Fed. Proc. 36, 2493-2503.

SCHMidT-NielseN B. \& Robinson R. R. (1970) Contribution of urea to urinary concentrating ability in the dog. Am. J. Fhysiol. 218, 1363-1369. 